\title{
The Implementation of Mind Mapping Model to Increase Motivation and Achievement of History Learning in SMA Negeri 1 Ngaglik
}

\author{
Jatrina $^{1}$, Sardiman ${ }^{2}$ \\ Graduate School, Universitas Negeri Yogyakarta ${ }^{1}$, Graduate School, Universitas Negeri Yogyakarta ${ }^{2}$ \\ Jatrina.2018@student.uny.ac.id ${ }^{1}$, Sardiman@uny.ac.id ${ }^{2}$
}

\begin{abstract}
The purpose of this research was to increase (1) motivation to learn history during the implementation of the Mind Mapping model, (2) student achievement after Mind Mapping implementation. This Class Action Research (CAR) used Kurt Lewin Method which includes planning, implementing, observing, and reflecting. The subjects of this study were 32 students of X IPS 1 SMA Negeri 1 Ngaglik, Sleman. The objects of this study were motivation, achievement, and Mind Mapping model. The results showed an increase in student motivation from 70.20 to 77.26 or had an increase of $7.06 \%$ in cycle II. The increase in student learning achievement can be seen from the initial condition average of 74.34 which increased to 77.85 or had an increase of $3.51 \%$ in cycle I, and increased to 85.30 or had an increase of $7.45 \%$ in cycle II. The initial passing grade was $56.25 \%$, in cycle I increased to $75 \%$ and in cycle II increased to $93.75 \%$.
\end{abstract}

Keywords: Learning Motivation, Learning Achievement and Mind Mapping

\section{Introducation}

SMA Negeri 1 Ngaglik Sleman Regency, Yogyakarta Province is a school with A accreditation. This school has 39 teachers, 230 male students, and 312 female students, 2 majors (natural science and social science), 22 classes, and 1 library. Many academic and nonacademic achievements and awards have been achieved by SMA Negeri 1 Ngaglik. SMAN 1 Ngaglik has a quite comfortable and beautiful environment with neat and clean classrooms making it comfortable for studying. In addition, there is a library for reading and doing group assignments. However, in the learning process at SMAN 1 Ngaglik, many teachers still use a model that does not involve students in learning and is teacher-centered, so students become passive. During the learning process, many students chat, use cellphones, and do not ask questions if they do not know so that the learning and teaching process is less effective.

In learning activities in X IPS 1, teachers still apply the teacher-centered method, so that students are bored, lazy in learning, do not pay attention to teachers, are busy talking with peers, busy using cellphones, and some even sleep in class. In addition, students are not on time when they enter the class and during the teaching and learning process.

This is supported by the results of interviews with the history teacher of X IPS I SMA Negeri 1 Ngaglik who stated that non-discipline causes lateness, so that students are less active in history lessons, students are busy using cell phones, talking with peers, even many students do not bring textbooks and only bring a worksheet. So that when students do assignments and do not find the answers on the worksheet, students will search the internet. This condition results in low motivation to study history. In addition, low achievement, where many students did not meet the specified passing grade, namely 75 . Of the 32 students, 18 
students or $56.25 \%$ had met the passing grade and the rest, 14 students or $43.75 \%$ had not met the passing grade. .

Therefore, in implementing the learning process, it is necessary to have learning innovations with various models that can increase motivation and achievement in history learning. One of the learning models that can increase motivation and learning achievement is Mind Mapping by Tony Buzan. He wrote about brain mapping patterns using new standards by the following brainstorming. A mind map is a diagram to present words, ideas, tasks, or other things that are connected from the main idea of the brain. A mind map is used to generalize, visualize, and classify ideas and as a medium in learning, organizing, problemsolving, decision making, and writing. This mind map is also a very appropriate model to describe the process easily and efficiently [1].

Based on the benefits obtained from the Mind Map to increase student motivation and achievement in History, especially students of X IPS 1 SMA Negeri 1 Ngaglik, the title of the research is "Implementation of Mind Mapping Model to Increase Motivation and Achievement of History Learning in SMA Negeri 1 Ngaglik".

\section{Literature Review}

History deals with scientific research procedures. History is also concerned with reasoning based on facts (in Latin, Factus means "something that is finished"). The truth of history lies in the willingness of historians to thoroughly examine historical sources so that it is hoped that historians will reveal them objectively. The final result that is expected is a match between historians and facts [2].

Philosophically, according to constructivism theory, learning is building knowledge gradually which is expanded through a limited context. Knowledge is not a set of facts, concepts, or rules that are taken or memorized. Humans must construct knowledge and give meaning through real experience. Borich and Tambari defined constructivism in learning is an approach that gives students the opportunity to construct meaning bit by bit of something learned by building relationships internally with the facts being taught. Constructivism in learning emphasizes that learning occurs only when students are active in cognitive structures and in schema-building experiences [3].

Students learn because of the boost of mental strength. Mental strength is in the form of desire, attention, or aspiration. The mental strength can be low and high. An educational psychologist stated that mental strength as a driving force for learning is called learning motivation. Motivation is considered a mental drive that directs human behavior, including learning behavior. In motivation, there is a desire that activates, moves, channels, and directs individual attitudes and behavior to learn [4].

Motivation can be internal and external. Several authors or experts mentioned intrinsic and extrinsic motivation. Internal or intrinsic motivation is the drive from within the individual to carry out activities [5]. Meanwhile, external motivation is a push that comes outside of the individual. Every student is expected to be motivated by internal motivation because it is a sign of an inner awareness of students to study seriously. However, this does not mean that external motivation does not have an important position for students, because the results of many studies also show that motivation is a factor that has a major influence on the achievement of learning outcomes or success. Learning outcomes can be seen in an achievement given by students, for example by mentioning the letters in the alphabet in 
sequence. Every proper achievement is an act of learning statement. Achievement is specific or is in one category because learning achievement is different, depending on the fields in which students show achievement, for example in the field of knowledge or understanding (cognitive fields) [6].

A mind map is a technique of utilizing the whole brain by using visual imagery and other graphic infrastructure to form impressions. The brain often remembers information in the form of pictures, symbols, sounds, forms, and feelings. The mind map uses these visual and sensory reminders in a pattern of related ideas such as the road map used for learning, organizing, and planning. This map can generate original ideas and trigger easy memories [7]. This is also calming, fun, and creative. Mind Mapping starts from a topic that is in the middle of the paper, then the sub-topics must be arranged randomly, but must be related to the main topic. This shows that Mind Mapping follows a pattern in describing information [8]. Mind Mapping allowing students to create visuals to enhance their learning [9]. Mind Mapping is one of the most revolutionary learning concepts in the educational world [10]. Mind Mapping is a technique of utilizing the entire brain using visual imagery and other graphical infrastructures to form a sense [11].

\section{Stages of Mind Mapping}

1) Deliver the learning objectives to be achieved.

2) The teacher presents the material

3) To determine the absorption of students, form groups of two people.

4) Have one of the pairs tell the material that has just been received from the teacher and the partner listens while making little notes, then changing roles. Likewise other groups.

5) All students take turns delivering the results of their interviews with their partners until some students have explained the results of the interview.

6) The teacher repeats or explains the material again if the students have not understood it.

7) Conclusion

The material in learning is taken from Basic Competencies, namely; 3.8 Analyzing the characteristics of community life, government and culture during the Islamic kingdoms in Indonesia and showing examples of evidence that still apply to Indonesian life today. This material discusses the process of entering and developing Indonesian Islamic religion and culture. The learning material that will be discussed is the acculturation and development of Islamic culture and the process of integration in the archipelago.

The research on Mind Mapping had been conducted by Dhida Dwi Kurniawati, a student from Muhammadiyah University of Surakarta with the title, "The Influence of Mind Mapping Method and Student Motivation on Social Science Learning Achievement in VII Students of Muhammadiyah 5 Junior High School in Surakarta in Academic Year 2009/2010 "which showed that the application of Mind Mapping model could improve the quality of learning in cycle 1 up to $75 \%$ while cycle II reached $100 \%$ [12].

\section{Method}

Class Action Research (CAR) is conducted to improve the quality of classroom learning practices. Class Action Research (CAR) focuses on a class or on the teaching and learning process that occurs in class, not on class input (syllabus, material, etc.) or output (learning outcomes). Class Action Research (CAR) must be focused on or about things that happen in the classroom. 
Class Action Research aims to improve real and practical problems in improving the quality of classroom learning that is experienced directly in interactions between teachers and students. The purpose of this research was to improve the learning process to increase motivation and achievement in history learning in X IPS 1 students at SMA Negeri 1 Ngaglik.

Class Action Research was carried out in the 2018/2019 academic year in the even semester which is March to May 2019 at SMA Negeri 1 Ngaglik. The subjects of this research were 32 students of X IPS 1 SMA Negeri 1 Ngaglik. The purpose of this research was to increase motivation and historical learning achievement by using Mind Mapping. Class Action Research arises because of the awareness of activity behavior that is not satisfied with work results [13]. CAR consists of research, action, and class. Research is an activity of observing an object by using certain methodological rules to obtain useful data and information in improving quality and attracting interest and importance to researchers [14].

Class Action Research (CAR) aims to improve the quality of classroom learning practices. This class action research used Kurt Lewin Model which includes planning, implementation, observation, and reflection which can be seen in the following figure:

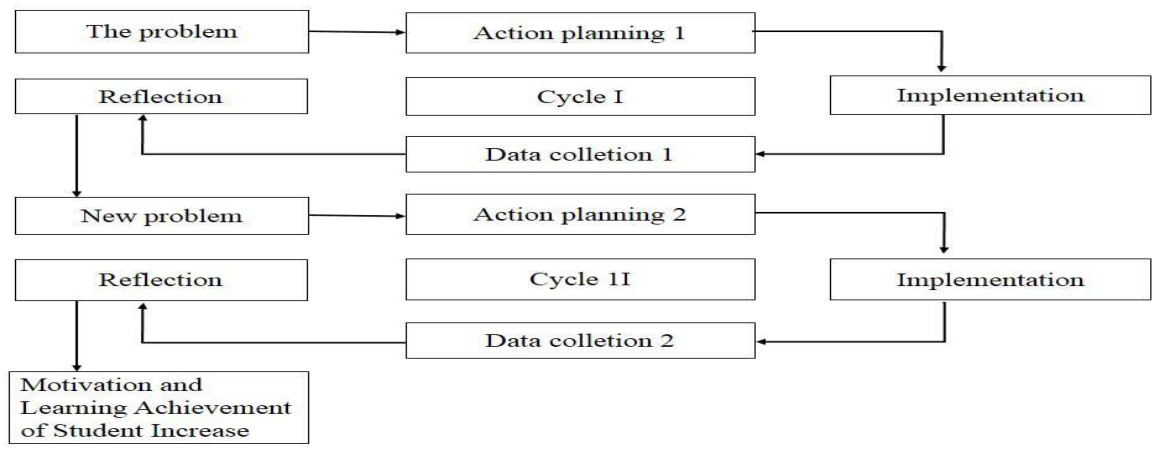

Fig.1. Research Stages [15]

Source: Suharsimi Arikunto, dkk. Class Action Research (CAR), 2016.

\section{Results and Discussion}

This class action research was conducted at SMAN 1 Ngaglik, Sleman Regency, Yogyakarta province. The object of the study was a grade $\mathrm{X}$ social science major 1 with a student total of 32 people. The study was conducted for 6 weeks, from April 15th to May 20th. In this research, the researchers conducted two cycles, namely cycle I and cycle II, but before carrying out cycles I and II, researchers first conducted pre-cycle to know the initial state before the model to be used in the learning process. In cycle I there was 3 times the meeting. The first and second meetings were used for the learning process activities while the third meeting was used for competency testing or tests. Cycle II was 2 times the meeting. The first meeting for the learning process activities while the second meeting was used for the competency test.

\section{Pre-Cycle}

Pre-cycle observation was conducted on 25 March 2019 in class X Social Science Major 1 SMAN 1 Ngaglik on historical subjects. This pre-cycle observation was performed during the 3rd and 4th lesson hours. Before the learning process was conducted there were some students 
who were late in class. After that, the student began opening up their student assignment papers. When teachers explained the learning material there were some students who were less concerned with what the teacher described. Then after that teachers gave questions on students, but only a few students can answer. Then the teacher formed a group to perform the discussion on questions that had been prepared by the teacher. After that, students conveyed the results of each group's discussion by one person as representative. The following table of students' learning activities on SMAN 1 Ngaglik in class.

Tabel 1. Data analysis of the initial state of student motivation

\begin{tabular}{|c|c|c|c|c|c|}
\hline No. & Criteria & $\begin{array}{c}\text { Motivation } \\
\text { Scales }\end{array}$ & Frequency & $\begin{array}{c}\text { Percentage } \\
(\%)\end{array}$ & Average \\
\hline 1. & Very High & $90-100$ & 0 & 0 & \multirow{6}{*}{70,20} \\
\hline 2. & High & $80-89$ & 0 & 0 & \\
\hline 3. & Enough & $70-79$ & 19 & 59,38 & \\
\hline 4. & Low & $60-69$ & 10 & 31,24 & \\
\hline 5. & Very Low & $0-59$ & 3 & 9,38 & \\
\hline & Total & & 32 & 100 & \\
\hline
\end{tabular}

In addition, researchers also saw the initial state of student motivation and learning achievement of the X-grade social science major 1 SMAN 1 Ngaglik. Here is a preliminary state diagram of motivational learning history:

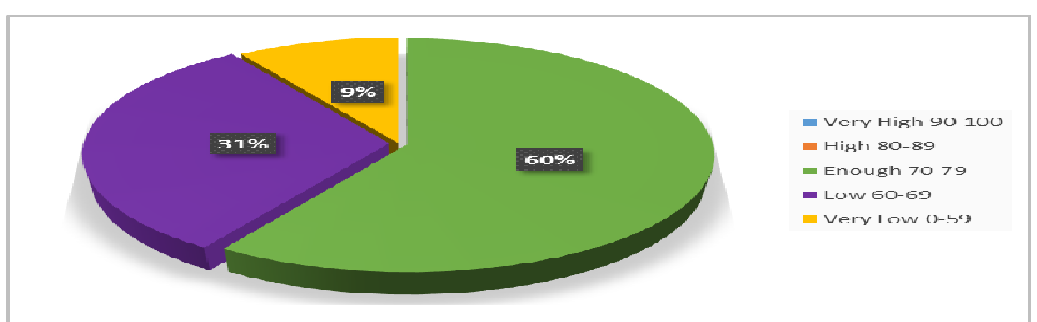

Fig.2. Preliminary State Diagram Motivation Learning Class X Social Science Major 1 Source : Personal data

The initial state of history learning achievement in class X IPS 1 SMA Negeri 1 Ngaglik shows that there are 14 students who have not reached the KKM or $43.75 \%$. Meanwhile, those who have reached the KKM are 18 students or $56.25 \%$. Based on these data, before applying the Mind Mapping learning model there were still some students who had not reached the KKM so that student achievement was low. Therefore it is necessary to improve by using the Mind Mapping learning model.To find out the criteria for the initial state of student achievement, it is shown in the table as follows:

Tabel 2. Pre cycle learning achievement analysis data

\begin{tabular}{llcccc}
\hline No. & Criteria & Motivation Scales & Frequency & Percentage (\%) & Average \\
\hline 1. & Very High & $90-100$ & $\mathbf{0}$ & $\mathbf{0}$ & $\mathbf{1 8 , 7 5}$ \\
2. & High & $80-89$ & $\mathbf{6}$ & $\mathbf{6 8 , 7 5}$ & $\mathbf{7 4 , 3 4}$ \\
3. & Enough & $70-79$ & $\mathbf{2 2}$ & $\mathbf{9 , 3 8}$ & $\mathbf{3 , 1 2}$ \\
4. & Low & $60-69$ & $\mathbf{3}$ & $\mathbf{1 0 0}$ & \\
5. & Very Low & $0-59$ & $\mathbf{1}$ &
\end{tabular}

Source : Personal data 
Based on the above data, students with low learning achievement criteria were still a lot of $9.38 \%$, and the lowest amount was $3.12 \%$, which was just $68.75 \%$, and that has a high achievement of $18.75 \%$. To know the percentage of students' learning achievement level history can be seen in the diagram below:

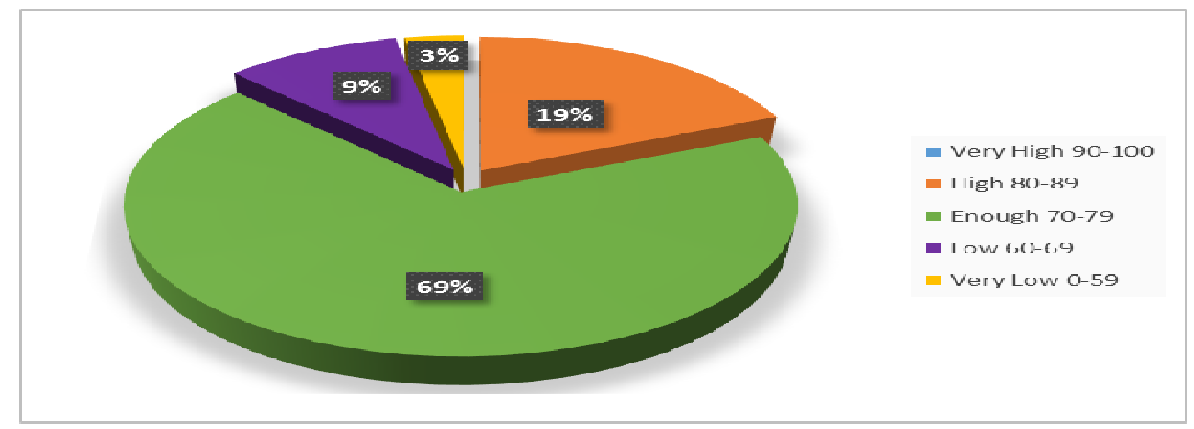

Fig.3. The Preliminary State Diagram Of Student Learning Achievement Source : Personal data

\section{Cycle I}

Cycle I was conducted to three meetings at the first and second meetings to perform the process of learning to teach at the first meeting on April 22, 2019, and the second meeting on April 29, 2019. While at the third meeting conducted a competency test. At the first meeting, the teaching material about "acculturation and the development of Islamic culture" was about the art of building, carving, and script and literary art. As for the second materials, "the arts, ceremonies and calendar systems". The process of learning began to applied Mind Mapping model.

In the first cycle learning achievement students' of history of class X social science major 1 SMAN 1 Ngaglik was measured based on the evaluation result of multiple-choice questions and essays done after application of Mind Mapping learning model. The minimum submission criteria (KKM) specified was 75 . Based on the data, the students with very low learning achievement criteria amounted to $12.5 \%$, and the low amounted to $6.25 \%$, on the criteria which amounted to $25 \%$, which has a high achievement of $43.75 \%$ and on the very high criteria amounted to $12.5 \%$. From the table above showed that there was a very highperformance enhancement. Although some students have not reached the minimum submission criteria. To see students ' learning achievements can be seen through the diagram below:

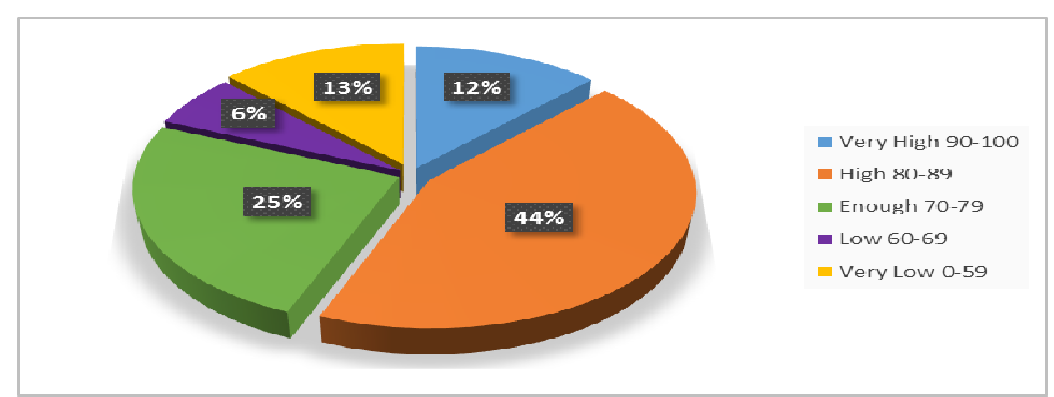

Fig.4. Achievement Diagram Learning Student History X Social Science Major 1 


\section{Source : Personal data}

In cycle I, motivation can be seen from the aspects of learning activities that students follow in the learning process in the classroom. An improvement occurs from the pre-cycle to the I cycle, although it has not been significant. That on cycle I have proved from the results of data that aspects of cooperating in a group, appreciating the opinions of friends, and listening to friends when group discussions experienced significantly from the pre-cycle to the I cycle. Furthermore, which was still to be improved in the process of learning activities was to take a turn during the discussion, responsible for the group, giving opinions, ideas and discussions, communicating answers. It was therefore continued on the II cycle to significantly experience.

In cycle I motivation can be seen from the aspects of learning activities that students follow in the learning process in the classroom. An improvement occurs from the pre-cycle to the I cycle, although it has not been significant. That on cycle I have proved from the results of data that aspects of cooperating in a group, appreciating the opinions of friends, and listening to friends when group discussions experienced significantly from the pre-cycle to the I cycle. Furthermore, which is still to be improved in the process of learning activities is to take a turn during a discussion, responsible for the group, giving opinions, ideas and discussions, communicating answers It is therefore continued on the II cycle to significantly experience.

\section{Cycle II}

Based on the above data, the motivation of class X social science major 1 has increased. This was indicated by the data mentioning 2 students or $6.25 \%$ was very high, the motivation of students who number 4 students or $12.5 \%$ was high, the motivation to learn the history of enough category was 24 or $75 \%$, motivation is relatively low number 2 students or $6.24 \%$ and in very low category there was none or $0 \%$. This has shown that motivation in historical learning was experiencing increased motivation. To find out the number of students learning motivation levels can be seen in the diagram below

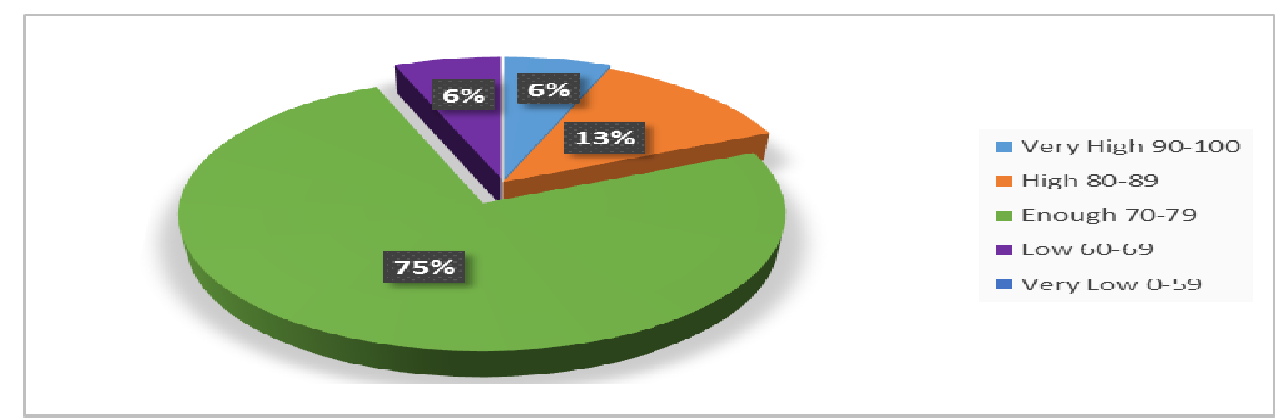

Fig.5. The Motivation State Diagram Of Learning Class X Social Science Major 1 Cycle II Source : Personal data

There was an increase in achievement of student history study, students with low and very low learning achievement criteria amounted to $0 \%$, on enough criteria amounting to $15.62 \%$, then on high criteria amounted to $40.63 \%$ and at very high criteria amounted to $43.75 \%$. The table above shows that there was a significant achievement improvement. To see students' learning achievements can be seen through the diagram below: 


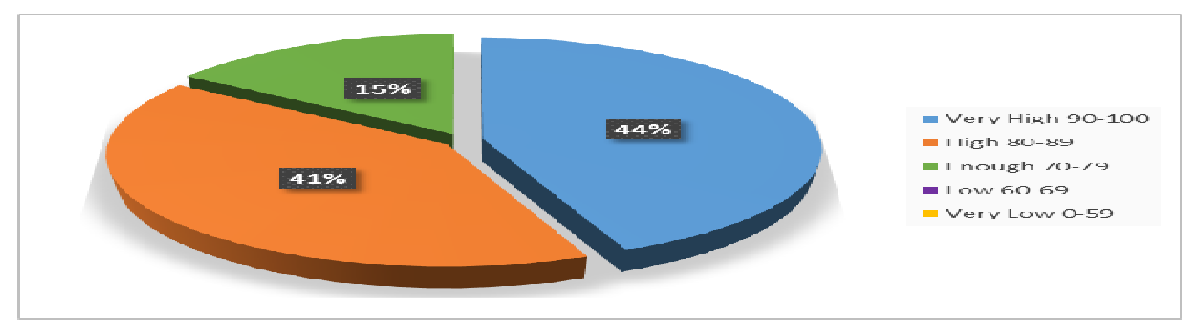

Fig.6. Learning achievement Diagram of cycle II students Source : Personal data

Table 3. Comparison of Level of Learning Motivation on Pre Cycle and Cycle II

\begin{tabular}{|c|c|c|c|c|c|c|c|c|}
\hline \multirow{2}{*}{ No. } & \multirow{2}{*}{ Criteria } & \multirow{2}{*}{$\begin{array}{c}\text { Motivation } \\
\text { Scales }\end{array}$} & \multicolumn{3}{|c|}{ Pre-Cycle } & \multicolumn{3}{|c|}{ Cycle II } \\
\hline & & & $\mathbf{F}$ & $\%$ & Average & $\mathbf{F}$ & $\%$ & Average \\
\hline 1. & Very High & $90-100$ & $\mathbf{0}$ & $\mathbf{0}$ & & 2 & 6,25 & \\
\hline 2. & High & $80-89$ & $\mathbf{0}$ & 0 & & 4 & 12,5 & \\
\hline 3. & Enough & $70-79$ & 19 & 59,38 & 70,20 & 24 & 75 & 77,26 \\
\hline 4. & Low & $60-69$ & 10 & 31,24 & & 2 & 6,25 & \\
\hline \multirow[t]{2}{*}{5.} & Very Low & $0-59$ & 3 & $\mathbf{9 , 3 8}$ & & $\mathbf{0}$ & $\mathbf{0}$ & \\
\hline & \multicolumn{2}{|c|}{ Total } & 32 & 100 & & 32 & 100 & \\
\hline
\end{tabular}

Based on the above data, it can be concluded that there was an increased learning motivation of students. Can be seen on the very low motivation criteria on pre-cycle numbered to $9.38 \%$ while in cycle II was $0 \%$. Furthermore, at low criteria when the pre-cycle amounted to $31.24 \%$ and when the cycle II was $6.24 \%$. Besides, on a pre-cycle enough criterion number was $31.24 \%$ and when the number II cycle increased to $75 \%$. The high criteria increased from the pre-cycle which amounted to $0 \%$ to $12.5 \%$ in cycle II. Also, at the highest criterion at the pre-cycle was $0 \%$ and in cycle II the number was up to $6.25 \%$. To know the increased motivation to learn students are seen in the diagram below

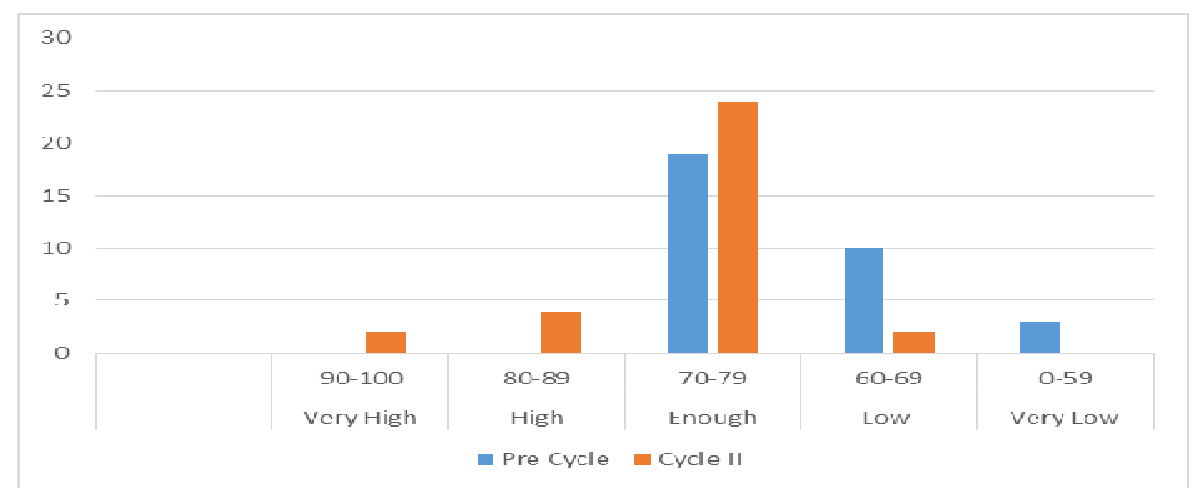

Fig.7. Comparison Diagram Of The Motivation To Learn For Pre-Cycle And Cycle I Source : Personal data 
Comparison of the results of the pre-cycle research, cycle I and cycle II are used to see an increase in students' learning performance after setting up the Mind Mapping learning model. The following was the result of the comparison of students' learning achievement XI Social Science Major 1 SMAN 1 Ngaglik:

Table 4. Comparison of Achievement Level

\begin{tabular}{|c|c|c|c|c|c|c|c|c|}
\hline \multirow{2}{*}{ No. } & \multirow{2}{*}{ Criteria } & \multirow{2}{*}{$\begin{array}{l}\text { Achievement } \\
\text { Scale }\end{array}$} & \multicolumn{3}{|c|}{ Pre-Cycle } & \multicolumn{3}{|c|}{ Cycle I } \\
\hline & & & F & $\%$ & Average & $\mathbf{F}$ & $\%$ & Average \\
\hline 1. & Very High & $90-100$ & $\mathbf{0}$ & 0 & \multirow{6}{*}{74,34} & 4 & 12,5 & \multirow{6}{*}{77,85} \\
\hline 2. & High & $80-89$ & 6 & 18,75 & & 14 & 43,75 & \\
\hline 3. & Enough & $70-79$ & 22 & 68,75 & & 8 & 25 & \\
\hline 4. & Low & $60-69$ & 3 & $\mathbf{9 , 3 8}$ & & 2 & 6,25 & \\
\hline 5. & Very Low & $0-59$ & 1 & 3,13 & & 4 & 12,5 & \\
\hline & & & 30 & 100 & & 32 & 100 & \\
\hline
\end{tabular}

Based on the table, a noticeable increase in the criteria of high learning achievement, it was indicated by a percentage amount that reached $12.5 \%$ on the cycle I, whereas at the precycle was only $0 \%$. Also, changes occurred in the criteria of high-learning performance at the pre-cycle amounted to $18.75 \%$ while the cycle of 1 amounted to $43.75 \%$. There was also an increase in enough achievement criteria in the pre-cycle amounted to $68.75 \%$, while cycle I amounted to $25 \%$. At the pre-cycle, low criteria amounted to $9.12 \%$, while the cycle I amounted to $6.25 \%$. Furthermore, at a very low criterion in the pre-cycle amounted to 3.12 , while the cycle I amounted to $12.5 \%$. To find out the improved learning performance on the pre-cycles and cycle I can be seen in the following diagram:

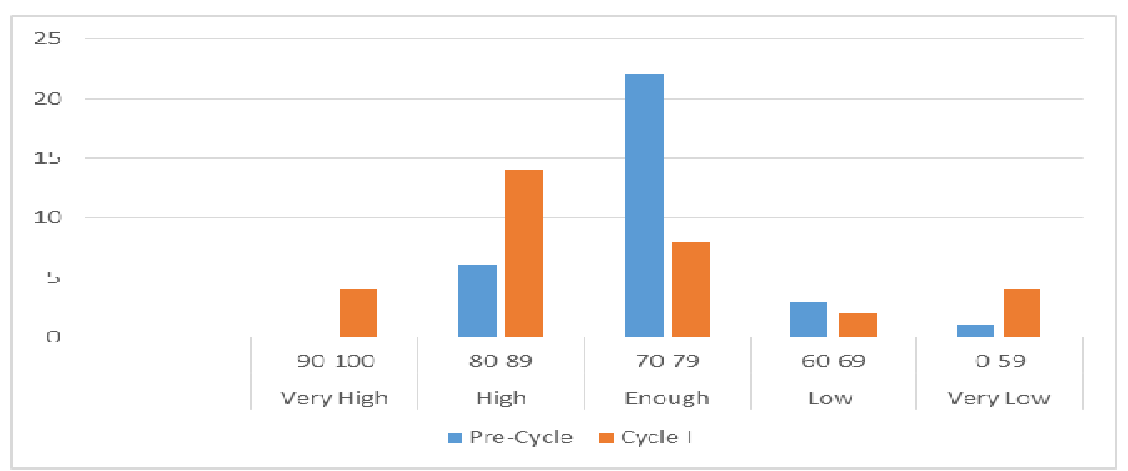

Fig.8. chart of pre-cycle study performance comparison with cycle 1 Source : Personal data

Table 5. Comparison Of Students Performance Level In Cycle I And Cycle II

\begin{tabular}{clccccccc}
\hline \multirow{2}{*}{ No. } & \multirow{2}{*}{ Criteria } & $\begin{array}{c}\text { Achievement } \\
\text { Scale }\end{array}$ & F & $\mathbf{\%}$ & Average & F & \% & Average \\
\hline 1. & Very High & $90-100$ & 4 & $\mathbf{1 2 , 5}$ & & $\mathbf{1 4}$ & $\mathbf{4 3 , 7 5}$ & \\
2. & High & $80-89$ & $\mathbf{1 4}$ & $\mathbf{4 3 , 7 5}$ & & $\mathbf{1 3}$ & $\mathbf{4 0 , 6 3}$ & \\
3. & Enough & $70-79$ & $\mathbf{8}$ & $\mathbf{2 5}$ & $\mathbf{7 7 , 8 5}$ & $\mathbf{5}$ & $\mathbf{1 5 , 6 2}$ & $\mathbf{8 5 , 3 0}$ \\
4. & Low & $60-69$ & $\mathbf{2}$ & $\mathbf{6 , 2 5}$ & & $\mathbf{0}$ & $\mathbf{0}$ & \\
5. & Very Low & $0-59$ & $\mathbf{4}$ & $\mathbf{1 2 , 5}$ & & $\mathbf{0}$ & $\mathbf{0}$ & \\
\hline & \multicolumn{1}{c}{ Total } & $\mathbf{3 2}$ & $\mathbf{1 0 0}$ & & $\mathbf{3 2}$ & $\mathbf{1 0 0}$ & \\
\hline
\end{tabular}




\section{Source : Personal data}

From the table, a very significant increase in the criteria of learning achievement was very high, it was indicated by a percentage number that reached $43.75 \%$ in cycle II, while in cycle I $12.5 \%$. As for the high criteria, changes in the I cycle amounted to $43.75 \%$ while the cycle II becomes $40.63 \%$. Changes also occur in enough criteria of learning achievement at Cycle I reached $25 \%$ reduced to $15.62 \%$. In the low criteria in cycle 1 amounted to $6.25 \%$ and very low amounted to $12.5 \%$, while for low and very low criteria in cycle II amounted to $0 \%$. To find out the improved learning performance in cycle I and cycle II can be seen in the following diagram:

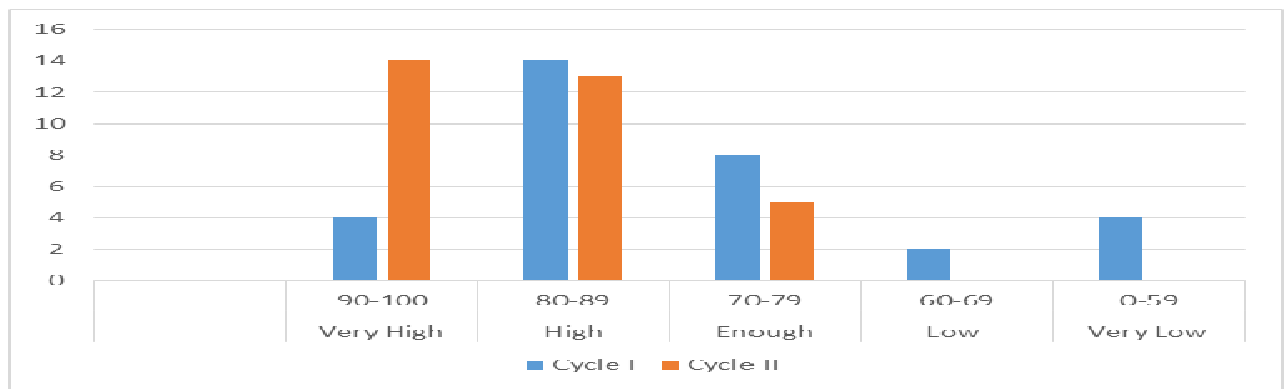

Fig.9. Performance Comparison Diagram Of The Cycle I Study With Cycle II Source : Personal data

\section{Conclusions}

Based on the results of research conducted on students of class X Social Science Major 1 SMAN 1 Ngaglik, can be taken in the conclusion as follows: The cooperative learning model of Mind Mapping can increase the motivation to learn the history of students of Class X Social Science Major 1 SMAN 1 Ngaglik, Sleman. This can be shown at the initial state of an average score of 70.20, and in cycle II has an increase of 77.26 or $7.06 \%$. Mind Mapping Learning Model can improve the learning performance of students ' history of class X Social Science Major 1 SMAN 1 Ngaglik, Sleman. This is shown in the number of students who meet the Minimal submission criteria (KKM). At the initial state of the average value of 74.34 , it increased to 77.85 or $3.51 \%$ in the I cycle, and increased to 85.30 or $7.45 \%$ in the II cycle. In terms of Minimal submission criteria (KKM) at the initial state reaching the KKM of $56.25 \%$, in the cycle I increased to $75 \%$, and in cycle II experienced an increase of $93.75 \%$.

\section{References}

[1] Utomo, D: Media pembelajaran aktif. Nuansa Cendekia, Bandung. pp. 72 (2013)

[2] Kuntowijoyo: Pengantar ilmu sejarah. Tiara Wacana, Yogyakarta. pp. 10. (2013)

[3] Baharuddin dan Esa Nur Wahyuni: Teori belajar dan pembelajaran. Ar-Ruzz Media, Yogyakarta. pp. 164-165 (2015)

[4] Dimyati dan Mudjiono: Belajar dan pembelajaran. Rineka Cipta, Jakarta. pp. 80 (2015)

[5] Anurrahman: Belajar dan pembelajaran. Alfabeta, Bandung. pp. 15 (2012)

[6] W.S. Winkel: Psikolagi pendidikan dan evaluasi belajar. PT Gramedia, Jakarta. pp. 48 (1984). 
[7] Shoimin, A: 68 model pembelajaran inovatif dalam kurikulum 2013. Ar-Ruzz Media, Yogyakarta. pp. 105 (2014)

[8] Utomo, D: Media pembelajaran aktif. Nuansa Cendekia, Bandung. pp. 73 (2013)

[9] B. D. Jones, C. R. Jennifer, D. S. Britta, Petrich, C. Koonce, The effects of mind mapping Activities on students' motivation. International Journal for the Scholarshop of Teaching and Learning. vol.6, pp. 3 (2012)

[10] Syam, N., Ramlah: Penerapan model pembelajaran mind mapping dalam meningkatkan hasil belajar pada mata pelajaran Ilmu Pengetahuan Sosial Siswa Kelas IV SDN 54 Kota Parepare. Jurnal Publikasi Pendidikan. Vol. V, pp. 184 (2015)

[11] Shoimin, A: 68 model pembelajaran inovatif dalam kurikulum 2013. Ar-Ruzz Media, Yogyakarta. pp. 63-64 (2014)

(12) Dhida Dwi Kurniawati: Pengaruh metode mind mapping dan motivasi belajar siswa terhadap prestasi belajar ilmu pengetahuan sosial pada siswa kelas vii sekolah menengah pertama Muhammadiyah 5 Surakarta Tahun Pelajaran 2009/2010. Universitas Muhammadiyah Surakarta. (2010)

[13] Arikunto, S: Penelitian tindakan kelas. Rineka Cipta, Jakarta. pp. 5 (2010)

[14] Mulia, D. S. Suwarno: PTK (Penelitian Tindakan Kelas) dengan pembelajaran berbasis kearifan lokal dan penulisan artikel ilmiah di Sd Negeri Kalisube , Jurnal Ilmiah Kependidikan, Banyumas. Vol. IX, pp. 3 (2016)

[15] Arikunto, S: Penelitian Tindakan Kelas. PT Bumi Aksara, Jakarta: pp. 144 (2016) 